\title{
Effect of calcium chloride and calcium lactate on shelf life extension of sweet orange
}

\author{
Sunila $^{1 *}$, Aysha Riaz ${ }^{1}$, Ziaur Rahman ${ }^{2}$, Nabila Khan ${ }^{2}$ and Mian \\ Ahmad Raza ${ }^{2}$ \\ 1. Department of Food Science and Technology, University of Agriculture, Peshawar-Pakistan \\ 2. Department of Agriculture, The University of Swabi, Swabi-Pakistan \\ *Corresponding author's email: sunilabegum@gmail.com
}

Citation

Sunila, Aysha Riaz, Ziaur Rahman, Nabila Khan and Mian Ahmad Raza. Effect of calcium chloride and calcium lactate on shelf life extension of sweet orange. Pure and Applied Biology. Vol. 9, Issue 2, pp1279-1293. http://dx.doi.org/10.19045/bspab.2020.90133

\begin{tabular}{llll}
\hline \hline Received: $29 / 09 / 2019$ & Revised: 07/12/2019 & Accepted: 14/01/2020 & Online First: $12 / 02 / 2020$ \\
\hline \hline
\end{tabular}

\section{Abstract}

An experiment was conducted to investigate the effect of calcium chloride and calcium lactate coating on sweet orange. The fruits were treated with different concentration of calcium chloride and calcium lactate $\mathrm{T}_{0}$ was use as control, $\mathrm{T} 1$ with $1 \%$ calcium chloride coating, T2 with $1.5 \%$ calcium chloride coating, T3 with $2 \%$ calcium chloride coating, T4 with $1 \%$ calcium lactate coating, T5 with $1.5 \%$ calcium lactate coating and T6 with $2 \%$ calcium lactate coating. Sweet oranges were stored for 35 days and analyzed after every 7 days during storage period. The stored samples were checked organoleptically for color, texture, taste, decay index and the overall acceptability and analyzed physicochemically for $\%$ acidity, total soluble solids (TSS), $\mathrm{pH}$, ascorbic acid, firmness and weight loss. An increase was noticed in physicochemical attributes which includes the increase of TSS from 6.07 to $9.64^{\circ}$ brix, the weight loss from 0 to $28.52 \%$, the $\mathrm{pH}$ from 3.80 to 4.17 and the decay index from 0 to $30.83 \%$. A decrease was noticed in the ascorbic acid from 76.04 to $47.98 \mathrm{mg} / 100 \mathrm{~g}$, titratable acidity from 2.92 to $2.12 \%$, and the firmness from 82.15 to $55.90 \mathrm{~kg} / \mathrm{cm}^{2}$. During the storage all organoleptic attributes decreased. The texture decreased from 8.60 to 5.80 , the color from 8.72 to 5.51, the taste from 8.62 to 5.71 and the overall acceptability decreased from 8.62 to 5.85 . From this research, it is reported that sample $\mathrm{T}_{3}$ with $2 \%$ calcium chloride followed by the $\mathrm{T}_{2}$ with $1.5 \% \mathrm{CaCl}_{2}$ was the best sample on the basis of the organoleptic and physicochemical attributes.

Keywords: Ascorbic Acid; Calcium chloride; Calcium lactate; Firmness; pH; Storage; Sweet orange; Titratable acidity; TSS; Weight loss

\section{Introduction}

Citrus is a vast kingdom that contains different cultivated species, including Citrus reticulate (tangerine \& mandarin), Cirrus sinensis (sweet orange), Citrus lemon (lemon), Citrus paradise (grapefruit) and Citrus grandis (pummelo). Citrus is one of the most vital fruit crop cultivated in Pakistan. Sweet orange is type of the fruit which belongs to citrus sinensis included in family Rutaceae [1]. The production of citrus was about 2396.2 tons per year, cultivated over an area of about 193.7 hectares. The regions in Pakistan where it is grown mostly are Punjab (Sargodha, Multan, Faisalabad, Bahawalpur, and Gujranwala) Quetta area 
of Balauchistan and Khyber Pakhtunkhwa [2].

Citrus fruits have a high commercial value in the fruit market. Among them, oranges can be considered as a good source of bioactive compounds, in which their consumption would have health benefits for humans. However, high moisture content and nutrient composition make this fruit more susceptible to fungi contamination. It should be noted that such products are also susceptible to softening, browning or color change and microbial contamination [3].

Methods have been studied to preserve and also extend shelf life of the commodities after harvesting [4]. The edible coatings techniques are commonly used for the improvement of the food appearance and the fruit preservation because they have the ability to provide the selective barriers against the moisture loss, decay and respiration [5]. Calcium plays a vital part in the fruit physiology such as calcium stabilizes the turgor pressure and the cell membranes. Calcium and the pectic acid combine in the fruit forming calcium pectate because of which the cell structure is stabilized. Moreover, it preserves the appearance of vegetables and fruits by preventing browning by means of reducing leakage of the polyphenol oxidase (PPO), its substrates on the cuts and the outer surfaces [6].

From previous work, observation has been made about the useful effects of calcium. It can be used to reduce respiration rate so the ripening and senescence slow down. Calcium plays a key role in stabilizing and giving mechanical hardness to the structure of cell which is the fruit stiffening agent. Calcium has been used more in the fruits and vegetables sector for the fresh cut, the overall commodities being as firming and a protective firming agent [7]. Almost in all previous work done the amount of calcium salts used ranges from $0.5-3 \%$ [8]. The bond between pectin and calcium become stronger by the addition of the calcium salt because of which the structure of cell wall become stiff [9]. Cell wall's cohesion increases due to presence of calcium ions, therefore decreases the ripening and senescence of the fruits because of the calcium application to the surface of fruit. Storage life of the fruit is enhanced to some extent and the softening is delayed for a little time period when the calcium chloride is used for the fruit treatment to that of the fruits which are untreated [9].

Treatments of $(\mathrm{Ca})$ either with calcium lactate or calcium chloride have made known to be very effective at retaining the firmness during the storage in various fresh cut vegetables and fruit studies. Some examples are mango $[10,11]$ carrot [12] melon [13-15]. Although the research study has been carried out about the applications of calcium to the fresh-cut mango but still it has not been used commercially. According to [16] the bitter and salty tastes related with calcium chloride are largely suppressed when calcium is combined with larger organic ions such as lactate, gluconate or glycerophosphate.

The use of calcium lactate and calcium chloride in different types of fruits as the firming agents is extensive. These compounds work as a result of binding to negatively charged carboxylic acid groups of the galacturonic acid remains in pectin chain and as a result forming an egg box gel model which results in firming up of the cell wall [17]. The losses after the harvest in the citrus fruits quality have commonly been observed [18]. The Biological [19] chemical and physical [20, 21] processes are usually taken on to eradicate the spores from fruits surfaces. The discussed methods are very effective to reduce the disease occurrence [22]. After harvesting the diseases damage almost (10\% to $30 \%$ ) of the entire yields, on the other hand in the unpreserved crops particularly in the developing countries the diseases damages more than $(30 \%)$ of the yield crop [11]. 
Keeping in view the above mentioned literature, this research was done to investigate the calcium lactate and calcium chloride effects on the qualities of the sweet oranges after harvesting.

\section{Materials and methods}

Orange fruits at maturity were taken from Manki sharif, Nowshehra and then brought to the food processing lab of
"Nuclear Institute for Food and Agriculture" Peshawar, Khyber Pakhtunkhwa, Pakistan where research work was carried out. Damaged and diseased portion of oranges was thrown away. The oranges were cleaned with water for the removal of dirt, dust and other chemicals.

\section{Plan of study}

Treatments

$\mathrm{T}_{0}$

$\mathrm{T}_{1}$

$\mathrm{T}_{2}$

$\mathrm{T}_{3}$

$\mathrm{T}_{4}$

$\mathrm{T}_{5}$

$\mathrm{T}_{6}$
Calcium chloride $(\%)$

Fresh sweet orange (control)

$1 \%$

$1.5 \%$

$2 \%$

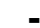

$-$
Calcium lactate $(\%)$

(control)

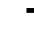

$1 \%$

$1.5 \%$

$2 \%$
Orange fruits were washed with tap water and dried under fan for 10-15 minutes. After the orange fruits were dried, they were divided into 7$)$ lots $\left(T_{0}, T_{1} T_{2}, T_{3}, T_{4}\right.$, $\mathrm{T}_{5}$, and $\mathrm{T}_{6}$ ). Each lot contained 50 fruits. The fruits were dipped in solution of calcium lactate and calcium chloride for five minutes, as per the plan of study. Orange fruits were kept at room temperature for a period of (35) days and analysis was done after every (7) days.

\section{Physicochemical analysis}

Weight loss; TSS; Fruit firmness; ascorbic acid; titratble acidity; $\mathrm{pH}$ and decay index were analyzed using AOAC methods [23].

\section{Sensory evaluation}

All the samples of orange fruit were investigated organoleptically for color, taste, texture and overall accessibility by the judges. The organoleptic analysis were evaluated for an interval of every 7 days at time of preservation for duration of 35days. Then it was evaluated using nine points of the hedonic scale of [24].

\section{Statistical analysis}

The data was documented for Variance Analysis using "Complete Randomized Design" (CRD) with 2 factors [25]. Statistical computer software "statistics" was used for calculating anova. Mean was separated by applying LSD test.

\section{Physicochemical analysis}

pH

The readings of all the samples of first day from $\mathrm{T}_{0}$ to $\mathrm{T}_{6}$ were $3.82,3.79,3.81,3.80$, $3.82,3.82,3.80$, which increased to 4.32 , $4.22,4.07,4.08,4.10,4.18,4.16$, respectively during the thirty-five days storage time period. The mean $\mathrm{pH}$ values for storage significantly $(\mathrm{p}<0.05)$ increased from 3.80 to 4.17 . The highest mean value observed in $\mathrm{T}_{0}$ (4.12) followed by $\mathrm{T}_{5}$ (4.09) whereas the minimum value was noted for $T_{3}$ and $T_{2}$ (3.92) followed by $T_{1}$ (3.96) in (Table 1). The statistical outcomes of the data have shown that both storage and the coating application had a significant $(\mathrm{p}<0.05)$ impact on the ph of orange fruit stored at room temperature (Appendix - VI). Similar trend of increasing ph with storage has also been published by [26] where $\mathrm{pH}$ increased from 3.60 to 3.83 in orange fruit. The increases in ph value of samples may be attributed to the decreasing acidity of the samples $[27,28]$ showed that ph increased from 4.035 to 5.910 within one month of storage using calcium chloride treatment on orange. 
In the treated fruits calcium chloride dip

effect the $\mathrm{pH}$ and titratable acidity.

Table 1. Effect of calcium chloride and calcium lactate coating on the $\mathrm{pH}$ of whole orange fruits during storage

\begin{tabular}{|c|c|c|c|c|c|c|c|c|}
\hline \multirow{2}{*}{ Treatments } & \multicolumn{7}{|c|}{ Storage intervals (days) } & \multirow{2}{*}{ Means } \\
\cline { 2 - 9 } & Initial & $\mathbf{7}$ & $\mathbf{1 4}$ & $\mathbf{2 1}$ & $\mathbf{2 8}$ & $\mathbf{3 5}$ & $\begin{array}{c}\text { \% } \\
\text { Increase }\end{array}$ & \\
\hline $\mathrm{T}_{0}$ & 3.82 & 3.94 & 4.14 & 4.32 & 4.22 & 4.32 & 13.0 & $4.12 \mathrm{a}$ \\
\hline $\mathrm{T}_{1}$ & 3.79 & 3.83 & 3.87 & 3.93 & 4.16 & 4.22 & 11.34 & $3.96 \mathrm{~d}$ \\
\hline $\mathrm{T}_{2}$ & 3.81 & 3.72 & 3.93 & 3.99 & 4.03 & 4.07 & 6.82 & $3.92 \mathrm{e}$ \\
\hline $\mathrm{T}_{3}$ & 3.80 & 3.78 & 3.91 & 3.95 & 4.05 & 4.08 & 7.36 & $3.92 \mathrm{e}$ \\
\hline $\mathrm{T}_{4}$ & 3.82 & 3.85 & 3.95 & 4.02 & 4.50 & 4.10 & 7.32 & $4.04 \mathrm{~b}$ \\
\hline $\mathrm{T}_{5}$ & 3.82 & 3.92 & 3.98 & 4.02 & 4.09 & 4.18 & 9.42 & $4.09 \mathrm{c}$ \\
\hline $\mathrm{T}_{6}$ & 3.80 & 3.89 & 4.01 & 4.13 & 4.14 & 4.16 & 9.47 & $4.02 \mathrm{bc}$ \\
\hline Means & $3.80 \mathrm{e}$ & $3.84 \mathrm{~d}$ & $3.97 \mathrm{c}$ & $4.05 \mathrm{~b}$ & $4.16 \mathrm{a}$ & $4.17 \mathrm{a}$ & & \\
\hline
\end{tabular}

The different letters figures are significantly different $(\mathrm{p}<0.05)$ from each other.

LSD value for treatments $=0.0995$

LSD value for storage intervals $=0.0921$

\section{Fruit firmness $\left(\mathbf{k g} / \mathrm{cm}^{2}\right)$}

The first day readings of all the samples from $\mathrm{T}_{0}$ to $\mathrm{T}_{6}$ were $81.25,82.22,82.44$, $82.67,82.10,81.98,82.40 \mathrm{~kg} / \mathrm{cm}^{2}$ which decreased to $52.74,51.85,60.73,59.68$, $54.46, \quad 55.35$, and $56.54 \mathrm{~kg} / \mathrm{cm}^{2}$ respectively during 35 days of storage. The mean firmness values for storage significantly $(\mathrm{p}<0.05)$ decreased from 82.15 to $55.90 \mathrm{~kg} / \mathrm{cm}^{2}$. For treatments lowest mean value was observed $\mathrm{T}_{0}$ (67.10) followed by $\mathrm{T}_{4}$ (67.49) while highest mean value was noted for $\mathrm{T}_{3}$ and $\mathrm{T}_{2}$ (71.01) followed by $\mathrm{T}_{1}$ (68.91) (Table $2)$. The statistical outcomes of the data revealed that both the coating application and storage period had a significant $(p<0.05)$ impact on the firmness of orange sample stored at room temperature (Appendix - III). Similar trend of decreasing firmness with storage has also been published by [26] where fruit firmness decreased was about $46 \%-57 \%$ in orange fruit [29] showed the same trend 15.7 to $10.2 \mathrm{~kg} / \mathrm{cm}^{2}$ of decreasing the firmness with in storage of 15 days in Jujube fruit. Calcium chloride retards the ripeness process, as indicated higher firmness lower activity of lipolytic enzymes relative to the control [30] showed that firmness decreased from 3.91 to $2.68 \mathrm{~kg} / \mathrm{cm}^{2}$ with in storage of 28 days in mandarin fruit. Firmness might be due to moisture loss from the fruits cells [31] showed that firmness decreases from 25 to $17.5 \mathrm{~kg} / \mathrm{cm}^{2}$ within 27 days of storage using $2 \% \mathrm{CaCl}_{2}$ for 2 minutes on apricot fruit [32] Also at their research showed that firmness decreases from 10 to 0.3 $\mathrm{kg} / \mathrm{cm}^{2}$ in apricot fruit. Calcium plays a key role in stabilizing and giving mechanical hardness to cell structure stiffing agent of fruits.

\section{Ascorbic acid (mg/100g)}

First day readings of all samples from $\mathrm{T}_{0}$ to $\mathrm{T}_{6}$ were $76.10,76.20,76.10,76.00$, $75.80,76.00$, and $76.10 \mathrm{mg} / 100 \mathrm{~g}$ which decreased to $44.42,50.30,51.48,52.52$, $42.14, \quad 45.55$, and $49.46 \mathrm{mg} / 100 \mathrm{~g}$ respectively during 35 days of storage. The mean Ascorbic acid values for storage significantly $(\mathrm{p}<0.05)$ decreased from 76.04 to $47.98 \mathrm{mg} / 100 \mathrm{~g}$. From treatments lowest mean value was observed in $\mathrm{T}_{0}$ (59.95) followed by $\mathrm{T}_{5}$ (59.84) while maximum highest mean was noted in $\mathrm{T}_{3}$ (65.74) followed by $\mathrm{T}_{2}$ (64.22) in (Table $3)$. The statistical outcomes of the data 
revealed that both the coating application and storage period had a significant $(\mathrm{p}<0.05)$ impact on the ascorbic acid of orange sample stored at room temperature (Appendix-IV). Similar trend of decreasing ascorbic acid content with storage has also been reported by [33] where the ascorbic acid content decreased from $71.149 \%$ to $45.734 \%$ in citrus [34] showed that ascorbic acid content decreases from $27.2 \mathrm{mg}-17.1 \mathrm{mg} / 100 \mathrm{~g}$ in grapes [35] showed that ascorbic acid content decreases from 1.57 to $0.85 \mathrm{mg} / 100 \mathrm{~g}$ in fig fruit [36] shows that ascorbic acid content decreases from 7.00 to $5.90 \mathrm{mg} \backslash 100 \mathrm{gm}$ in plum during their 15 days of storage interval in plum fruit of calcium application. [37] showed that ascorbic acid decreased from 32.61 to $22.67 \%$ with in storage of 28 days in mandarin fruit. Vitamin $\mathrm{C}$ decreasing due to degradation of the ascorbic acid during the storage. Calcium delays the oxidation process of the fruit and maintaining ascorbic acid content in fruits. Vitamin $\mathrm{C}$ decline with in storage intervals is due to oxidation process [38].

Table 2. Effect of calcium chloride and calcium lactate coating on the firmness $\left(\mathrm{kg} / \mathrm{cm}^{2}\right)$ of whole orange fruits during storage

\begin{tabular}{|c|c|c|c|c|c|c|c|c|}
\hline \multirow{2}{*}{ Treatments } & \multicolumn{7}{|c|}{ Storage intervals (days) } & \multirow{2}{*}{ Means } \\
\cline { 2 - 9 } & Initial & $\mathbf{7}$ & $\mathbf{1 4}$ & $\mathbf{2 1}$ & $\mathbf{2 8}$ & $\mathbf{3 5}$ & $\begin{array}{c}\text { \% } \\
\text { Decreas } \\
\mathbf{e}\end{array}$ & \\
\hline $\mathrm{T}_{0}$ & 81.25 & 76.32 & 69.14 & 64.55 & 58.62 & 52.74 & 35.08 & $67.10 \mathrm{~g}$ \\
\hline $\mathrm{T}_{1}$ & 82.40 & 76.86 & 70.95 & 66.40 & 60.31 & 56.54 & 31.38 & $68.91 \mathrm{c}$ \\
\hline $\mathrm{T}_{2}$ & 82.44 & 77.44 & 72.11 & 67.42 & 64.38 & 60.73 & 26.33 & $70.75 \mathrm{~b}$ \\
\hline $\mathrm{T}_{3}$ & 82.67 & 78.54 & 73.04 & 68.67 & 63.49 & 59.68 & 27.80 & $71.01 \mathrm{a}$ \\
\hline $\mathrm{T}_{4}$ & 82.10 & 75.39 & 70.47 & 64.22 & 58.33 & 54.46 & 50.75 & $67.49 \mathrm{f}$ \\
\hline $\mathrm{T}_{5}$ & 81.98 & 76.40 & 71.59 & 65.34 & 59.20 & 55.35 & 32.48 & $68.31 \mathrm{~d}$ \\
\hline $\mathrm{T}_{6}$ & 82.22 & 72.21 & 70.03 & 65.43 & 59.71 & 51.85 & 36.93 & $67.74 \mathrm{e}$ \\
\hline Means & $82.15 \mathrm{a}$ & $76.88 \mathrm{~b}$ & $71.04 \mathrm{c}$ & $66.00 \mathrm{~d}$ & $60.57 \mathrm{e}$ & $55.90 \mathrm{f}$ & & \\
\hline
\end{tabular}

Different letters figures are significantly different $(\mathrm{p}<0.05)$ from each other.

LSD value for treatments $=1.5322$

LSD value for storage intervals $=1.4186$

Table 3. Effect of calcium lactate and calcium chloride coating on ascorbic acid (mg/100g) on whole orange fruits during storage

\begin{tabular}{|c|c|c|c|c|c|c|c|c|}
\hline \multirow{2}{*}{ Treatments } & \multicolumn{7}{|c|}{ Storage intervals (days) } & \multirow{2}{*}{ Means } \\
\cline { 2 - 9 } & Initial & $\mathbf{7}$ & $\mathbf{1 4}$ & $\mathbf{2 1}$ & $\mathbf{2 8}$ & $\mathbf{3 5}$ & $\begin{array}{c}\text { \% } \\
\text { Decrease }\end{array}$ & \\
\hline $\mathrm{T}_{0}$ & 75.80 & 71.44 & 62.30 & 57.80 & 50.49 & 42.14 & 44.40 & $59.95 \mathrm{~g}$ \\
\hline $\mathrm{T}_{1}$ & 76.20 & 70.37 & 65.00 & 59.27 & 54.39 & 50.30 & 51.49 & $62.58 \mathrm{~d}$ \\
\hline $\mathrm{T}_{2}$ & 76.10 & 71.00 & 67.53 & 61.50 & 57.72 & 51.48 & 32.35 & $64.22 \mathrm{~b}$ \\
\hline $\mathrm{T}_{3}$ & 76.00 & 74.11 & 69.29 & 64.37 & 58.16 & 52.52 & 30.89 & $65.74 \mathrm{a}$ \\
\hline $\mathrm{T}_{4}$ & 76.10 & 69.63 & 63.29 & 55.81 & 49.80 & 44.42 & 41.62 & $59.84 \mathrm{f}$ \\
\hline $\mathrm{T}_{5}$ & 76.00 & 70.38 & 63.50 & 56.17 & 51.80 & 45.55 & 40.06 & $60.56 \mathrm{e}$ \\
\hline $\mathrm{T}_{6}$ & 76.10 & 69.10 & 65.47 & 60.13 & 56.18 & 49.46 & 35.00 & $62.47 \mathrm{c}$ \\
\hline Means & $76.04 \mathrm{a}$ & $70.86 \mathrm{~b}$ & $65.19 \mathrm{c}$ & $59.29 \mathrm{~d}$ & $54.07 \mathrm{e}$ & $47.98 \mathrm{f}$ & & \\
\hline
\end{tabular}

Figures with different letters are significantly different $(\mathrm{p}<0.05)$ from each other.

LSD value for treatments $=0.9350$

LSD value for storage intervals $=2.0625$ 


\section{Weight loss (\%)}

First day readings of all samples from $\mathrm{T}_{0}$ to $\mathrm{T}_{6}$ were 0 , which increased to 9.5 , $15.92,19.31,20.83,24.93,26.41,29.29$, $30.80,32.45$, and $33.42 \%$ individually during their 35 days of storage. Maximum mean value in $\mathrm{T}_{0}$ (17.24) was determined by control followed by $\mathrm{T}_{4}$ (17.34) while minimum value was in $\mathrm{T}_{3}$ (10.15) followed by $\mathrm{T}_{2}$ (14.23). Maximum $\%$ increase was (78.72) followed by (73.92) in (Table 4). The statistical analysis of the obtained data of treatment and storage showed a significant $(p<0.05)$ change effect on the whole orange samples (Appendix -I). Same trend of increasing weight loss was also observed by [39]. They found increase in weight loss from $0-19.4 \%$. Weight loss was because of rate of transpiration and respiration, as calcium chloride treatment reduced the rate of transpiration and respiration so the fruits treated with calcium chloride has less weight loss as compared to other treatments. Calcium chloride was very effective as compare to lactate in decreasing weight loss percent. [40] also showed same result. For every 5 days interval during a storage period of
(25) days, there was a significant increase in weight loss from $1.039 \%$ to $8.014 \%$ in sweet orange [41] also showed the same result. There was a significant increase from (0\%-25) weight loss significantly increased from 0 to $25 \%$ within storage intervals of 30 days. Calcium chloride treatment on orange. [42]. showed that weight loss increased from 5.61 to 18.07 with in storage of 28 days in mandarin fruit. Losses in the peel moisture content and weight loss were mostly due to the transpiration process in fruits which resulted in dried-up appearance and wilted rind [43]. Showed that weight loss increases from 0 to $10 \%$ within 27 days of storage using $3 \% \mathrm{Cacl}_{2}$ for 2 minutes in apricot fruit [44]. Showed the same increase in weight loss from 0 to $17 \%$ with 20 days of storage in strawberry fruit. Calcium chloride act as a physical barrier for transcription loses [40]. The natural process like senescence, ripening and respiration are delayed by calcium [45] and the water loss through the processes like transpiring and respiration resulted in more weight loss during storage time period of fruits.

Table 4. Effect of calcium lactate and calcium chloride coating on weight loss (\%) of whole orange fruits during storage

\begin{tabular}{|c|c|c|c|c|c|c|c|c|}
\hline \multirow{2}{*}{ Treatments } & \multicolumn{7}{|c|}{ Storage intervals (days) } & \multirow{2}{*}{ Means } \\
\cline { 2 - 9 } & Initial & $\mathbf{7}$ & $\mathbf{1 4}$ & $\mathbf{2 1}$ & $\mathbf{2 8}$ & $\mathbf{3 5}$ & $\begin{array}{c}\text { \% } \\
\text { Increase }\end{array}$ & \\
\hline $\mathrm{T}_{0}$ & 0 & 9.85 & 15.92 & 20.83 & 26.41 & 33.42 & 33.42 & $17.24 \mathrm{a}$ \\
\hline $\mathrm{T}_{1}$ & 0 & 6.22 & 12.13 & 17.81 & 24.34 & 29.24 & 29.24 & $14.96 \mathrm{~d}$ \\
\hline $\mathrm{T}_{2}$ & 0 & 7.72 & 12.67 & 18.18 & 21.83 & 24.93 & 24.93 & $14.23 \mathrm{e}$ \\
\hline $\mathrm{T}_{3}$ & 0 & 5.52 & 8.36 & 12.47 & 15.24 & 19.31 & 19.31 & $10.15 \mathrm{f}$ \\
\hline $\mathrm{T}_{4}$ & 0 & 9.85 & 15.92 & 20.83 & 26.41 & 30.80 & 30.80 & $17.23 \mathrm{ab}$ \\
\hline $\mathrm{T}_{5}$ & 0 & 7.72 & 12.67 & 18.18 & 23.55 & 29.29 & 29.29 & $15.46 \mathrm{c}$ \\
\hline $\mathrm{T}_{6}$ & 0 & 8.64 & 15.98 & 20.84 & 25.45 & 32.45 & 32.45 & $17.23 \mathrm{ab}$ \\
\hline Means & $0 \mathrm{f}$ & $7.79 \mathrm{e}$ & $13.08 \mathrm{~d}$ & $18.52 \mathrm{c}$ & $23.31 \mathrm{~b}$ & $28.52 \mathrm{a}$ & & \\
\hline
\end{tabular}

Different letters figures are significantly different $(\mathrm{p}<0.05)$ from each other.

LSD value for treatments $=0.3702$

LSD value for storage intervals $=2.1999$

\section{Total soluble solid $\left({ }^{\circ}\right.$ Brix)}

At the initial day of the research the TSS values of samples were $6.0,6.0,6.1,5.8$, $6.20,6.00,6.10^{\circ}$ from $\mathrm{T}_{0}$ to $\mathrm{T}_{6}$ which increased to $10.60,9.30,9.00,8.8,10.80$, $9.50,9.50^{\circ}$ respectively during the storage period of (35) days. There was significant increase in the mean values of storage 
$(\mathrm{p}<0.05)$ increased from 6.07 to $9.64^{\circ}$. From treatments the highest value observed was in $\mathrm{T}_{0}$ (8.78) followed by $\mathrm{T}_{4}$ (8.71) whereas the lowest mean value was noted for $T_{3}$ and $T_{2}$ (7.71) followed by $T_{1}$ (7.83) (Table 5). The statistical outcomes of the data revealed that both the coating application and storage period had a significance $(p<0.05)$ impact on the TSS of orange sample stored at room temperature (Appendix-II). Similar trend of increasing TSS with storage has also been published by [44]. Where they analyzed increased in TSS from 8.37$10.93 \%$ in peach. TSS increases in citrus is because of complex carbohydrates break down into sugar and moisture content of the fruit become lowering [40] also analyzed same result TSS increases from $10.47 \%-11.11 \%$ in sweet orange within 30 days of storage time [45] showed that TSS increases from 7.48 to $9.24 \mathrm{mg} \backslash 100 \mathrm{gm}$ in plum during the 15 days of storage interval. [30] showed that TSS increased from 10.92 to $12.88 \%$ with in storage of 28 days in mandarin fruit. In untreated fruits the faster increase in the TSS was because of the faster activities of metabolic through the transpiration and respiration process. Calcium chloride maintaining TSS, it may possibly be because of the calcium inhibitory effect that is responsible for turgor pressure failure and build up membrane integrity. Increase in the TSS is result of polysaccharides enzymatic alteration such as starches and pectin into simple sugar during the ripening stage 53 [31] showed that TSS increases from 11.5 to 13.5 within 27 days of storage using $1 \% \mathrm{CaCl}_{2}$ for 2 minutes in apricot fruit.

Table 5. Effect of calcium lactate and calcium chloride coating on TSS (Brix) on whole orange fruits during storage

\begin{tabular}{|c|c|c|c|c|c|c|c|c|}
\hline \multirow{2}{*}{ Treatments } & \multicolumn{7}{|c|}{ Storage intervals (days) } & \multirow{2}{*}{ Means } \\
\cline { 2 - 9 } & Initial & $\mathbf{7}$ & $\mathbf{1 4}$ & $\mathbf{2 1}$ & $\mathbf{2 8}$ & $\mathbf{3 5}$ & $\begin{array}{c}\text { \% } \\
\text { Increase }\end{array}$ & \\
\hline $\mathrm{T}_{0}$ & 6.0 & 7.60 & 8.50 & 9.40 & 10.20 & 10.60 & 76.60 & $8.78 \mathrm{a}$ \\
\hline $\mathrm{T}_{1}$ & 6.0 & 6.90 & 7.40 & 8.50 & 8.90 & 9.30 & 55.00 & $7.83 \mathrm{~d}$ \\
\hline $\mathrm{T}_{2}$ & 6.1 & 7.00 & 7.50 & 8.20 & 8.80 & 9.00 & 47.50 & $7.76 \mathrm{e}$ \\
\hline $\mathrm{T}_{3}$ & 5.8 & 6.8 & 8.00 & 8.4 & 8.5 & 8.8 & 51.72 & $7.71 \mathrm{f}$ \\
\hline $\mathrm{T}_{4}$ & 6.20 & 7.50 & 8.30 & 9.50 & 10.40 & 10.80 & 74.19 & $8.71 \mathrm{~b}$ \\
\hline $\mathrm{T}_{5}$ & 6.00 & 7.50 & 8.00 & 8.60 & 9.10 & 9.50 & 58.33 & $8.11 \mathrm{c}$ \\
\hline $\mathrm{T}_{6}$ & 6.10 & 7.60 & 7.90 & 8.70 & 9.00 & 9.50 & 55.73 & $8.13 \mathrm{c}$ \\
\hline Means & $6.07 \mathrm{f}$ & $7.27 \mathrm{e}$ & $7.94 \mathrm{~d}$ & $8.75 \mathrm{c}$ & $9.27 \mathrm{~b}$ & $9.64 \mathrm{a}$ & & \\
\hline
\end{tabular}

Figures with different letters are significantly different $(\mathrm{p}<0.05)$ from each other.

LSD value for treatments $=0.3786$

LSD value for storage intervals $=0.3488$

\section{Percent acidity (\%)}

The first day readings of all the samples from $\mathrm{T}_{0}$ to $\mathrm{T}_{6}$ were $2.87,2.92,2.88,2.95$, $2.90,2.91,2.94 \%$ respectively which decreased to $1.94,1.97,2.12,2.43,2.08$, $2.16,2.15 \%$ respectively during storage period of (35) days. The mean percent acidity values for storage significantly $(p<0.05)$ decreased from 2.91 to 2.12 . From treatments lowest mean value was observed in $\mathrm{T}_{0}$ (2.39) followed by $\mathrm{T}_{4}$ (2.46) while minimum highest mean was noted in $T_{3}$ and $T_{2}$ (2.69) followed by $T_{1}$ (2.50) in (Table 6). The statistical outcomes of the obtained data showed that both the storage period and coating application had a significant $(\mathrm{p}<0.05)$ impact on the percent acidity of orange sample stored at room temperature (Appendix-V). Similar trend of decreasing 
percent acidity with storage has also been published by [44] analyzed same decrease in $\%$ acidity from $(0.907)$ to $(0.734)$ in peach during their storage interval of one month [33] attributed the same decrease in $\%$ acidity from (1.68) to (0.75) in sweet orange during their storage interval. The decreases in \% acidity may be due to pattern of senescence [35] showed that acidity decreases from $0.53 \%$ to $0.35 \%$ with in storage interval in fig fruit [46] showed that acidity decreases from 1.590 to 1.244 in plum during their 15 days of storage interval [37] showed that acidity decreased from 0.86 to 0.53 with in storage of 28 days in mandarin fruit. During storage time period the acidity descending trend was because of the acid utilization in tricarboxylic acid cycle in the respiration process [43] showed that acidity decreases from 2.5 to 2.00 within 27 days of storage using $1 \% \mathrm{CaCl}_{2}$ for 2 minutes in apricot fruit. Fruits oxidation reaction is reduced by calcium of fruits and also fruits metabolic process is delayed [31]. Also it brings less decrease in the titratibility acidity.

Table 6. Effect of calcium chloride and calcium lactate coating on acidity (\%) of whole orange fruits during storage

\begin{tabular}{|c|c|c|c|c|c|c|c|c|}
\hline \multirow{2}{*}{ Treatments } & \multicolumn{7}{|c|}{ Storage intervals (days) } & \multirow{2}{*}{ Means } \\
\cline { 2 - 9 } & Initial & $\mathbf{7}$ & $\mathbf{1 4}$ & $\mathbf{2 1}$ & $\mathbf{2 8}$ & $\mathbf{3 5}$ & $\begin{array}{c}\text { \% } \\
\text { Decrease }\end{array}$ & \\
\hline $\mathrm{T}_{0}$ & 2.87 & 2.74 & 2.46 & 2.25 & 2.10 & 1.94 & 32.40 & $2.39 \mathrm{~d}$ \\
\hline $\mathrm{T}_{1}$ & 2.92 & 3.06 & 2.70 & 2.33 & 2.09 & 1.97 & 32.53 & $2.50 \mathrm{~b}$ \\
\hline $\mathrm{T}_{2}$ & 2.88 & 2.79 & 2.63 & 2.58 & 2.24 & 2.12 & 26.38 & $2.54 \mathrm{~b}$ \\
\hline $\mathrm{T}_{3}$ & 2.95 & 2.77 & 2.77 & 2.68 & 2.54 & 2.43 & 17.62 & $2.69 \mathrm{a}$ \\
\hline $\mathrm{T}_{4}$ & 2.90 & 2.62 & 2.53 & 2.40 & 2.28 & 2.08 & 28.27 & $2.46 \mathrm{c}$ \\
\hline $\mathrm{T}_{5}$ & 2.91 & 2.77 & 2.58 & 2.46 & 2.30 & 2.16 & 25.77 & $2.53 \mathrm{~b}$ \\
\hline $\mathrm{T}_{6}$ & 2.94 & 2.66 & 2.68 & 2.41 & 2.29 & 2.15 & 26.86 & $2.25 \mathrm{~b}$ \\
\hline Means & $2.91 \mathrm{a}$ & $2.77 \mathrm{~b}$ & $2.6 \mathrm{c}$ & $2.44 \mathrm{~d}$ & $2.26 \mathrm{e}$ & $2.12 \mathrm{c}$ & & \\
\hline
\end{tabular}

Different letters figures are significantly different $(\mathrm{p}<0.05)$ from each other.

LSD value for treatments $=0.1129$

LSD value for storage intervals $=0.1220$

\section{Decay index (\%)}

All the readings of first day samples from $\mathrm{T}_{0}$ to $\mathrm{T}_{6}$ were 0 , from $\mathrm{T}_{0}$ to $\mathrm{T}_{6}$ respectively which increased to $40.25,27.64,26.51$, $22.91, \quad 33.57, \quad 31.12$, and $33.87 \%$ respectively during the storage period of 35 days. The storage mean decay index values increased significantly $(\mathrm{p}<0.05)$ from 0 to $30.83 \%$. From treatments the highest mean value observed was $\mathrm{T}_{0}$ (16.69) followed by $\mathrm{T}_{5}$ (13.58) while the lowest mean was noted for $\mathrm{T}_{3}$ and $\mathrm{T}_{2}$ (9.94) followed by $T_{1}$ in (Table 7 ). The statistical outcomes of the data showed that both storage period and the coating application had a significant $(\mathrm{p}<0.05)$ impact on the decay index of orange sample stored at room temperature (Appendix -VII). Similar trend of increasing decay index with storage has also been published by [47] where decay index increased from (0) to (42.73) in peach fruit coating of calcium lactate. The increase in decay index value of samples may be attributed to the increasing decay index of the samples [48] analyzed same increase in decay index may be from (0) to (4.5) in grapes during their storage interval [37] showed that decay index increased from 1.89 to 16.70 with in storage of 28 days in mendareine fruit [5] also showed the same increase which were from 0 to 24.44 within 20 days of storage interval in tomato fruit. Increase in decay was due to 
delay senescence that makes the commodities weaker to the pathogenic infection as the tissue or cellular integrity loss. The membrane is protected from lipid degradation by the calcium ions by making stable plasma membrane. This reduces the degradation chances bylipolytic enzymes. Calcium bridges formed in the cell walls have to reduce approach to bacterial hydrolysis or fungal that cause decay [49].

Table 7. Effect of calcium chloride and calcium lactate coating on Decay index (\%) of orange fruit during storage

\begin{tabular}{|c|c|c|c|c|c|c|c|c|}
\hline \multirow{2}{*}{ Treatments } & \multicolumn{7}{|c|}{ Storage intervals (days) } & \multirow{2}{*}{ Means } \\
\cline { 2 - 9 } & Initial & $\mathbf{7}$ & $\mathbf{1 4}$ & $\mathbf{2 1}$ & $\mathbf{2 8}$ & $\mathbf{3 5}$ & $\begin{array}{c}\mathbf{\%} \\
\text { Increase }\end{array}$ & \\
\hline $\mathrm{T}_{0}$ & 0 & 4.45 & 7.28 & 17.48 & 30.66 & 40.25 & 40.25 & $16.69 \mathrm{a}$ \\
\hline $\mathrm{T}_{1}$ & 0 & 3.41 & 6.72 & 13.12 & 19.95 & 27.64 & 27.64 & $11.81 \mathrm{e}$ \\
\hline $\mathrm{T}_{2}$ & 0 & 3.32 & 6.38 & 12.28 & 20.15 & 26.51 & 26.51 & $11.44 \mathrm{f}$ \\
\hline $\mathrm{T}_{3}$ & 0 & 3.12 & 5.68 & 11.17 & 16.72 & 22.91 & 22.91 & $9.94 \mathrm{~g}$ \\
\hline $\mathrm{T}_{4}$ & 0 & 3.56 & 6.58 & 13.13 & 24.69 & 33.57 & 33.57 & $13.58 \mathrm{~b}$ \\
\hline $\mathrm{T}_{5}$ & 0 & 3.83 & 6.48 & 13.21 & 23.32 & 31.12 & 31.12 & $13.00 \mathrm{~d}$ \\
\hline $\mathrm{T}_{6}$ & 0 & 3.75 & 7.18 & 12.95 & 22.78 & 33.87 & 33.87 & $13.43 \mathrm{c}$ \\
\hline Means & $0.00 \mathrm{f}$ & $3.63 \mathrm{e}$ & $6.61 \mathrm{~d}$ & $13.33 \mathrm{c}$ & $22.61 \mathrm{~b}$ & $30.83 \mathrm{a}$ & & \\
\hline
\end{tabular}

Different letters figures are significantly different $(\mathrm{p}<0.05)$ from each other.

LSD value for treatments $=2.8684$

LSD value for storage intervals $=2.6556$

\section{Sensory evaluation}

\section{Color}

Initially the judges awarded the mean score for color samples were 8.6, 8.7, 8.7, $8.7,8.8,8.8,8.8$ from $\mathrm{T}_{0}$ to $\mathrm{T}_{6}$ respectively which increased to $5.0,5.5,5.9,6.4,5.2$, $5.7,4.9$ respectively during the storage period of (35) days. The mean color values for storage significantly $(\mathrm{p}<0.05)$ decreased from 8.72 to 5.98. From treatments highest mean value was observed in $T_{0}$ (6.70) followed by $T_{4}$ (6.78) while minimum lowest mean was noted for $T_{3}$ and $T_{2}$ (7.61) followed by $T_{1}$ (7.11) in (Table 8). The statistical outcomes of the data revealed that both the coating application and storage period had a significant $(\mathrm{p}<0.05)$ impact on the color of orange sample stored at room temperature (Appendix-VIII). The means were applied by applying LSD test at 5\% probability the values obtained (Table 4.8). Similar trend of decreasing with storage has also been published by [48] Calcium chloride and calcium lactate retard the peel physiology and also improve shining.]58 also showed decreased in appearance which was from 4.75 to 2.39 during their storage interval [5]. Also showed the same decrease which were from 8 to 4.4 within 20 days of storage interval in tomato fruit. Color score decreases with time due to loss of water content, which effects the fruits quality [50]. The same result showed by [51] too, who stated that the fruits quality may possibly be effected because of the respiration process.

Calcium chloride with edible coating material reduces the fruits respiration rate and others biological process.

\section{Texture}

Initially judges score for texture samples were 8.6, 8.5, 8.7, 8.6, 8.6, 8.5, 8.7 from $\mathrm{T}_{0}$ to $\mathrm{T}_{6}$ respectively which decreased to 4.7, 4.7, 5.1, 5.5, 4.8, 5.0, 5.1 respectively during storage period of 35 days. The mean storage Texture values decreased significantly $(\mathrm{p}<0.05)$ from 8.60 to 5.80 . From treatments the highest mean value observed was in $\mathrm{T}_{0}$ (6.60) followed by $\mathrm{T}_{5}$ (6.50) while minimum lowest mean was noted in $T_{3}$ and $T_{2}$ (6.86) followed by $T_{1}$ 
(6.68) in (Table 4.9). The statistical outcomes of the data showed that the both the coating application and storage period had a significant $(\mathrm{p}<0.05)$ impact on the texture of orange sample stored at room temperature (Appendix-IX). The means were applied by applying LSD test at 5\% probability values obtained (Table 9). Similar trend of decreasing with storage has also been published by [52] where texture decrease from 7.04-5.04 in sweet orange. At the stage of ripening and maturation protopect were slowly break down into lower molecular weight fraction that which are soluble in $\mathrm{H}_{2} \mathrm{O}$ and became

Table 8 . Effect of calcium chloride and judges) on orange fruits during storage

\begin{tabular}{|c|c|c|c|c|c|c|c|c|}
\hline \multirow{2}{*}{ Treatments } & \multicolumn{7}{|c|}{ Storage intervals (days) } & \multirow{2}{*}{ Means } \\
\cline { 2 - 8 } & Initial & $\mathbf{7}$ & $\mathbf{1 4}$ & $\mathbf{2 1}$ & $\mathbf{2 8}$ & $\mathbf{3 5}$ & $\begin{array}{c}\text { \% } \\
\text { Decrease }\end{array}$ & \\
\hline $\mathrm{T}_{0}$ & 8.6 & 7.8 & 7.1 & 6.3 & 5.4 & 5.0 & 41.86 & $6.70 \mathrm{~g}$ \\
\hline $\mathrm{T}_{1}$ & 8.8 & 8.1 & 7.5 & 6.7 & 6.1 & 5.5 & 37.5 & $7.11 \mathrm{c}$ \\
\hline $\mathrm{T}_{2}$ & 8.7 & 8.2 & 7.8 & 7.0 & 6.5 & 5.9 & 32.18 & $7.35 \mathrm{~b}$ \\
\hline $\mathrm{T}_{3}$ & 8.8 & 8.5 & 7.9 & 7.3 & 6.8 & 6.4 & 27.27 & $7.61 \mathrm{a}$ \\
\hline $\mathrm{T}_{4}$ & 8.7 & 7.9 & 7.0 & 6.3 & 5.6 & 5.2 & 40.22 & $6.78 \mathrm{f}$ \\
\hline $\mathrm{T}_{5}$ & 8.7 & 8.0 & 7.2 & 6.6 & 6.0 & 5.7 & 34.48 & $7.03 \mathrm{~d}$ \\
\hline $\mathrm{T}_{6}$ & 8.8 & 8.0 & 7.4 & 6.4 & 5.5 & 4.9 & 44.31 & $6.83 \mathrm{e}$ \\
\hline Means & $8.72 \mathrm{a}$ & $8.07 \mathrm{~b}$ & $7.41 \mathrm{c}$ & $6.65 \mathrm{~d}$ & $5.98 \mathrm{e}$ & $5.51 \mathrm{f}$ & & \\
\hline
\end{tabular}

Different letters figures are significantly different $(\mathrm{p}<0.05)$ from each other.

LSD value for treatments $=0.3510$

LSD value for storage intervals $=0.2323$

Table 9. Effect of calcium lactate and calcium chloride coating for texture (mean score of judges) on orange fruits during storage

\begin{tabular}{|c|c|c|c|c|c|c|c|c|}
\hline \multirow{2}{*}{ Treatments } & \multicolumn{7}{|c|}{ Storage intervals (days) } & \multirow{2}{*}{ Means } \\
\cline { 2 - 8 } & Initial & $\mathbf{7}$ & $\mathbf{1 4}$ & $\mathbf{2 1}$ & $\mathbf{2 8}$ & $\mathbf{3 5}$ & $\begin{array}{c}\text { \% } \\
\text { Decrease }\end{array}$ & \\
\hline $\mathrm{T}_{0}$ & 8.6 & 7.7 & 7.0 & 6.3 & 5.3 & 4.7 & 45.34 & $6.60 \mathrm{c}$ \\
\hline $\mathrm{T}_{1}$ & 8.5 & 6.8 & 6.8 & 5.9 & 6.4 & 4.7 & 44.70 & $6.68 \mathrm{~b}$ \\
\hline $\mathrm{T}_{2}$ & 8.7 & 7.9 & 6.8 & 6.2 & 5.5 & 5.1 & 41.37 & $6.70 \mathrm{~b}$ \\
\hline $\mathrm{T}_{3}$ & 8.6 & 7.7 & 7.0 & 6.5 & 5.9 & 5.5 & 36.04 & $6.86 \mathrm{a}$ \\
\hline $\mathrm{T}_{4}$ & 8.6 & 7.8 & 6.9 & 6.1 & 5.4 & 4.8 & 44.18 & $6.60 \mathrm{c}$ \\
\hline $\mathrm{T}_{5}$ & 8.5 & 7.5 & 6.8 & 6.0 & 5.2 & 5.0 & 41.17 & $6.50 \mathrm{~d}$ \\
\hline $\mathrm{T}_{6}$ & 8.7 & 7.4 & 7.4 & 6.8 & 5.8 & 5.1 & 41.37 & $6.70 \mathrm{~b}$ \\
\hline Means & $80.60 \mathrm{a}$ & $7.54 \mathrm{~b}$ & $6.95 \mathrm{c}$ & $6.25 \mathrm{~d}$ & $5.54 \mathrm{e}$ & $5.80 \mathrm{f}$ & & \\
\hline
\end{tabular}

Different letters figures are significantly different $(\mathrm{p}<0.05)$ from each other.

LSD value for treatments $=0.2960$

LSD value for storage intervals $=0.2740$ the reasons for softening $[39,53]$ showed that texture decreases from 6.2 to 4.3 during one month of storage in apricot fruit [54] showed that texture decreases from 3.37 to 1.89 within 14 days of storage in fig fruit. Calcium chloride coating maintain the texture of orange fruit. Same result are also demonstrated by [55]. The firmness in the fruits was retained by calcium chloride for a longer period, this was because membrane integrity is maintained by calcium, in results maintained the fruits structure for a longer time period [56]. 


\section{Taste}

At the beginning of this research the Taste scores for samples were 8.7, 8.6, 8.6, 8.7, $8.6,8.6,8.6$ from $\mathrm{T}_{0}$ to $\mathrm{T}_{6}$ respectively which decreased to5.2, 5.7, 5.8, 6.3, 5.4, 6.1 and 5.5 respectively for storage duration for (35) days. The mean taste values decreased significantly for storage $(\mathrm{p}<0.05)$ decreased from 86.2 to 5.71 . From treatments highest mean value was observed in $\mathrm{T}_{0}$ (6.73) followed by $\mathrm{T}_{4}$ (6.88) while minimum lowest mean was noted in $\mathrm{T}_{3}$ and $\mathrm{T}_{2}$ (7.53) followed by $\mathrm{T}_{1}$ (7.03) in (Table 10). The statistical outcomes of the data revealed that both the coating application and storage period had a potential $(\mathrm{p}<0.05)$ impact on the taste of orange sample stored at room temperature (Appendix-X). The means were applied by applying LSD test at 5\% probability values obtained (Table 4.10). Similar trend of decreasing with storage has also been published by [56] analyzed decreases which may be 6.42-2.81 in sweet orange during their storage interval. Taste of fruits is due to sugar acid ratio but also due to volatile components. Sweetness in fruit is due to sugar and sourness is because of acid $[39,54]$ showed that taste decreases from 6.9 to 6.1 during 30 days of storage in apricot fruit [57] also showed decreased in taste which was from 4.50 to 3.02 during their storage interval. Calcium chloride coating are the best coating for delaying ripening and slow down respiration process and slow onset of senesce.

Table 10. Effect of calcium lactate and calcium chloride coating for taste (mean scores of judges) on orange fruits during storage

\begin{tabular}{|c|c|c|c|c|c|c|c|c|}
\hline \multirow{2}{*}{ Treatments } & \multicolumn{7}{|c|}{ Storage intervals (days) } & \multirow{2}{*}{ Means } \\
\cline { 2 - 9 } & Initial & $\mathbf{7}$ & $\mathbf{1 4}$ & $\mathbf{2 1}$ & $\mathbf{2 8}$ & $\mathbf{3 5}$ & $\begin{array}{c}\text { \% } \\
\text { Decrease }\end{array}$ & \\
\hline $\mathrm{T}_{0}$ & 8.7 & 7.7 & 6.9 & 6.3 & 5.6 & 5.2 & 40.22 & $6.73 \mathrm{f}$ \\
\hline $\mathrm{T}_{1}$ & 8.6 & 7.8 & 7.3 & 6.7 & 6.1 & 5.7 & 33.72 & $7.03 \mathrm{~d}$ \\
\hline $\mathrm{T}_{2}$ & 8.6 & 8.1 & 7.8 & 7.1 & 6.4 & 5.8 & 32.55 & $7.30 \mathrm{~b}$ \\
\hline $\mathrm{T}_{3}$ & 8.7 & 8.2 & 7.8 & 7.3 & 6.9 & 6.3 & 27.58 & $7.53 \mathrm{a}$ \\
\hline $\mathrm{T}_{4}$ & 8.6 & 7.9 & 7.2 & 6.4 & 5.8 & 5.4 & 37.20 & $6.88 \mathrm{e}$ \\
\hline $\mathrm{T}_{5}$ & 8.6 & 8.0 & 7.5 & 6.9 & 6.5 & 6.1 & 29.06 & $7.26 \mathrm{c}$ \\
\hline $\mathrm{T}_{6}$ & 8.6 & 7.9 & 7.3 & 6.9 & 6.0 & 5.5 & 36.04 & $7.03 \mathrm{~d}$ \\
\hline Means & $8.62 \mathrm{a}$ & $7.94 \mathrm{~b}$ & $7.40 \mathrm{c}$ & $6.80 \mathrm{~d}$ & $6.18 \mathrm{e}$ & $5.71 \mathrm{f}$ & & \\
\hline
\end{tabular}

Different letters figures are significantly different $(\mathrm{p}<0.05)$ from each other.

LSD value for treatments $=0.2195$

LSD value for storage intervals $=0.2032$

\section{Overall acceptability}

The initial mean score by the judges for the overall acceptability samples were 8.7 , 8.6, 8.68.7, 8.6, 8.6, 8.6 from $\mathrm{T}_{0}$ to $\mathrm{T}_{6}$ respectively which decreased to $4.7,5.8$, $6.2,6.3,5.9,6.0$, and 6.1 respectively for storage duration for 35 days. The mean overall acceptability values for storage significantly $(\mathrm{p}<0.05)$ decreased from 8.62 to 5.85. From treatments the highest mean value observed was in $\mathrm{T}_{0}(6.58)$ followed by $\mathrm{T}_{4}$ (7.06) while minimum lowest mean was noted in $T_{3}$ and $T_{2}$ (7.41) followed by $\mathrm{T}_{1}$ (7.38) in (Table 11). The statistical outcomes of the data revealed that both the coating application and storage period had a potential $(\mathrm{p}<0.05)$ impact on the overall acceptability of orange sample stored at room temperature (Appendix-XI). Similar trend of decreasing with storage has also been published that decreases in overall acceptability are due to their high respiration rate $[39,49]$ showed that overall acceptability of apricot fruit 
decreases from 7.3to 5.2 within a month of storage. Within the storage, orange fruits quality was significantly maintained by coating of calcium chloride. The overall loss in the orange fruits quality might be because of the fruits progressive degradation with increase storage duration [57].

Table 11. Effect of calcium lactate and calcium chloride coating for overall (mean scores of judges) acceptability on orange fruits during storage

\begin{tabular}{|c|c|c|c|c|c|c|c|c|}
\hline \multirow{2}{*}{ Treatments } & \multicolumn{7}{|c|}{ Storage intervals (days) } & \multirow{2}{*}{ Means } \\
\cline { 2 - 9 } & Initial & $\mathbf{7}$ & $\mathbf{1 4}$ & $\mathbf{2 1}$ & $\mathbf{2 8}$ & $\mathbf{3 5}$ & $\begin{array}{c}\text { \% } \\
\text { Decrease }\end{array}$ & \\
\hline $\mathrm{T}_{0}$ & 8.7 & 7.7 & 7.0 & 6.4 & 5 & 4.7 & 46.51 & $6.58 \mathrm{~g}$ \\
\hline $\mathrm{T}_{1}$ & 8.6 & 7.9 & 7.4 & 6.8 & 6.3 & 5.8 & 32.55 & $7.13 \mathrm{e}$ \\
\hline $\mathrm{T}_{2}$ & 8.6 & 8.1 & 7.6 & 7.2 & 6.6 & 6.2 & 27.90 & $7.38 \mathrm{~b}$ \\
\hline $\mathrm{T}_{3}$ & 8.7 & 8.1 & 7.5 & 7.2 & 6.7 & 6.3 & 27.58 & $7.41 \mathrm{a}$ \\
\hline $\mathrm{T}_{4}$ & 8.6 & 7.6 & 7.2 & 6.8 & 6.3 & 5.9 & 31.39 & $7.06 \mathrm{f}$ \\
\hline $\mathrm{T}_{5}$ & 8.6 & 8.1 & 7.7 & 7.2 & 6.5 & 6.0 & 30.23 & $7.35 \mathrm{c}$ \\
\hline $\mathrm{T}_{6}$ & 8.6 & 7.8 & 7.5 & 6.9 & 6.4 & 6.1 & 29.06 & $7.21 \mathrm{~d}$ \\
\hline Means & $8.62 \mathrm{a}$ & $7.90 \mathrm{~b}$ & $7.41 \mathrm{c}$ & $6.92 \mathrm{~d}$ & $6.25 \mathrm{e}$ & $5.85 \mathrm{f}$ & & \\
\hline
\end{tabular}

Different letters figures are significantly different $(\mathrm{p}<0.05)$ from each other.

LSD value for treatments $=0.2740$

LSD value for storage intervals $=0.3702$

\section{Conclusion}

From the overall results it can be concluded that Calcium chloride and calcium lactate have the ability to decrease orange fruits post-harvest losses. The results also showed that sample $\mathrm{T}_{3}$ with $2 \% \mathrm{CaCl}_{2}$ followed by $\mathrm{T}_{2}$ with $1.5 \%$ $\mathrm{CaCl}_{2}$ was considered as the best sample on the basis of physicochemical and organoleptic quality. The storage stability of treated fruits was higher as compared to control fruits.

\section{Authors' contributions}

Conceived and designed the experiments: Sunila \& A Riaz, Performed the experiments and analyzed the data: Mian A Raza, Contributed materials/ analysis/ tools: N Khan \& Sunila, Wrote the paper: Z Rahman \& Sunila.

\section{Acknowledgement}

We are extremely thankful to all the authors who helped in the article. Sunila and Aysha Riaz conceived and designed the experiment and contributed analysis tools and reagents. Ziaur Rahman and Sunila wrote the paper and Nabila khan provided assistance in the experiment and reagents while Mian Ahmad raza analyzed the data.

\section{References}

1. Etebu E \& Nwauzoma AB (2014). A review on sweet orange (citrus synesis osbesk) health disease and management. American J Res Commu 2(2): 33-70.

2. Agriculture Statistics of Pakistan (2014-2015). Ministry of Food and Agri cooperation, Food and Agri. Div. (planning Unit), Islamabad.

3. Dhall RK (2013). Advances in edible coatings for fresh fruits and vegetables: a review. Critical Rev in Food Sci and Nutr 53(5): 435-450.

4. Falcao-rodrigues M, Maldao-Martins M \& Costa LBD (2007). DSC is a tool to assess physiological evaluation of apples preserved by edible coatings. Food Chem 102: 475-480.

5. Ali A, Mahmud TM, Sijam K \& Siddiqui Y (2011). Effect of chitosan coatings on the physico-chemical characteristics of eksotika II papaya. (Carica papaya) fruit during cold storage. Food Chem 124: 620-626. 
6. Lara I, Garcia P \& Vendrell M (2004). Modifications in cell wall composition after cold storage of calcium-treated strawberry (Fragaria $\mathrm{x}$ ananassa Duch.) Postharvest. Biol Tech 3(3): 331-339.

7. Chardonnet CO, Charron CS, Sams CE \& Conway WS (2003). Chemical changes in theoretical tissue and cell walls of calcium infiltrated golden delicious apples during storage. Postharvest Bio Tech 28: 97-111.

8. Martin-Diana \& Belen A (2006). Calcium for extending the shelf life of fresh whole and minimally processed fruits and vegetables: a review. Trends Food Sci Tech 18(4): 210-218.

9. Akhtar A, Abbasi NA \& Hussain A (2010). Effect of calcium chloride treatment on quality characteristics of loquat fruit during storage. Pak J Bot 42: 181-188.

10. Chantanawarangoon $S \&$ Kader AA (2000). Calcium treatments and modified atmospheres extended postcutting life of mango cubes. In Institute of Food Technologists Annual Meeting.

11. Kader A (2002). Post-harvest Technology of Horticultural Crops. $3^{\text {rd }}$ Edition University of California, Agriculture and Natural Resources. Pub. 3311.

12. Rico D, Martin-Diana ABJ, Frias, Barat JM, Henehan GTM \& BarryRyan C (2007). Improvement in texture using calcium lactate and heatshock treatments for stored ready-toeat carrots. J Food Eng 79: 1196-206.

13. Silveira AC, Aguayo E, Chisari M \& Artes F (2011). Calcium salts and heat treatment for quality retention of fresh-cut 'Galia' melon. Postharvest Bio.

14. Beirao-da-Costa S, Cardoso A, Martins L, Empis J \& Moldão-Martins (2008). The effect of calcium dips combined with mild heating of whole kiwifruit for fruit slices quality maintenance. Food Chem 108(1): 191197.

15. Martin-Diana \& Belen A (2006). Calcium for extending the shelf life of fresh whole and minimally processed fruits and vegetables: a review. Trends Food Sci Tech 18(4): 210-218.

16. Lawless HT, Rapacki F \& Hayes J (2003). The taste of calcium and magnesium salts and anionic modifications. Food Qual Prefer 14: 319-325.

17. Grant CWM \& Mcconnel HM (1973). Fusion of phospholipids vesicles with viable acholeplasma laidlawii. 70: 1238-1240.

18. Tariq MA, Tahir FM, Asi AA \& Iqbal J (2001). Effect of washing and seal packaging on scuffing damaged citrus fruit quality. Int J Agric Biol 3: 461463.

19. Kinay, P., Yildiz MF, Delen N \& Tosum N (2001). Control of postharvest decay of citrus fruits with antagonistic yeasts and chemical fungicides. Acta Hort 553: 383-388.

20. Smilanick JL, Sorenson D, Mansoor M, Aieyabel J \& Plaza P (2003). Impact of a brief postharvest hot water drench treatment on decay, fruit appearance and microbe populations of California lemons and oranges. Hort Tech 13: 333-338.

21. Paolo R, Santina, EB \& Intelisano $S$ (2004). Storage temperature effects on blood orange fruit quality. J Agric Food Chem 49: 3230-3235.

22. Abdel-El-Aziz, $S \&$ Mansoor $F$ (2006). Some safe treatment for controlling postharvest diseases of valencia orange (Citrus sinensis L.) fruits. J Annals Agric Sci 44: 135-146.

23. AOAC (2012). Official Methods of Analysis. The association of official analytical Chemist, $17^{\text {th }}$ Edn. Chapter 17.

24. Larmond E (1977). Laboratory methods of survey evaluation of food publication in Canada. Deptt of Agri Ottawa 30: 78-88. 
25. Steel RG \& Torrie JH (1997). Principles and procedures of statistics. A biometrical approach, $2^{\text {nd }}$ New York, M. c Graw-Hill, pp 633.

26. Chafer M, Sanchez-Gonzalez L, ChGonzalez M \& Chiralt A (2012). Fungal Decay and shelf life of oranges coated with chitosan and Bergamot, Thume and Tea Tree Essential Oils. $J$ Food Sci 77(8): 182-187.

27. Ibrahim MA (2016). Effect of different storage conditions on $\mathrm{pH}$ and vitamin $\mathrm{C}$ content in some selected fruit juice. Int J Biochem Res 11(2): 15.

28. Israel SA (2009). The preservative efficacies of bemul-wax coatings in combination with calcium chloride dip on low temperature stored Citrus O. sinensis. Int $J$ 21: 9-16.

29. Rokaya, PR., Baral DR, Gautam DM, Shrestha AK \& Paudyal KP (2016). Effect of postharvest treatments on quality and shelf Life of mandarin (Citrus reticulata Blanco). J Plant Sci 7(7): 1098.

30. Le'on, JA editors. Advance in postharvest treatments and fruit quality and safety. New York: Nova publisher.

31. Le'on, JA editors. Advance in postharvest treatments and fruit quality and safety. New York: Nova publisher.

32. Rab A, Haq S, Khalil SA \& Ali SG (2010). Fruit quality and senescence related changes in sweet orange cultivar blood red uni-packed in different packaging material. Sarhad $J$ Agric 26(2): 221-227.

33. Shahkoomahally, A \& Asghar R (2013). Effect of natural aloe vera gel coating combined with calcium chloride and citric acid Treatments on grape. American J Food Sci Res 2(1): $1-5$.

34. rfan PK., Vanjakshic V, Prakasha MNK, Ravie R \& Kudachikar VB (2013). Calcium chloride extend the keeping quality of fig fruit
(Ficuscarica L.) during storage and shelf life. Post-harvest Bio and Tech 82: 70-7.

35. Kirmani SN, Wani GM, Wani MSM, Ghani M, Abid M, Muzamil S, Raja S \& Malik AR (2013). Effect of pre harvest application of calcium chloride, gibberellic acid and naphthelenic acetic acid on storage of plum (Prunussalicina L.) cv. Santa Rosa under ambient storage conditions. African J Agri Res 8(9): 812-818.

36. Hayat I, Masud $\mathrm{T} \&$ Rathore HA (2003). Effect of coating and wrapping materials on shelf life of apple (Malusdomestica cv. Borkh). Intern J Food Safety (5): 24-34.

37. Kinh AE, Shearer CP \& Hoover DG (2001). Preservation of guava pulp with chemical preservatives and mild heat. J Food Prof 28(6): 111-114.

38. Wani, A. M., Hussain PR, Meena RS \& Dar MA (2008). Effect of gammairradiation and refrigerated storage on the improvement of quality and shelf life extension of pears (Pyruscommunis L., Cv. Bartlett/ William). Chem 77: 983-989.

39. Asghar A, Alamzeb F, Qazi IM, Ahmad S, Sohail M, Islam S \& Shinwari AS (2014). Effect of edible gum coating, glycerin and calcium lactate treatment on the post-harvest quality of peach fruit. Food Sci Quality Manag 30: 40-47.

40. Alzamora SM, Salvatori D, Tapia MS, Lopez-Malo A, WeltiChanes J \& Fito $P$ (2005). Novel functional foods from vegetable matrices impregnated with biologically active compounds. $J$ Food Engin 67: 205e214.

41. Rab A, Haq S, Khalil SA \& Ali SG (2010). Fruit quality and senescence related changes in sweet orange cultivar blood red uni-packed in different packaging material. Sarhad J Agric 26(2): 221-227.

42. Kinh AE, Shearer CP \& Hoover DG (2001). Preservation of guava pulp 
with chemical preservatives and mild heat. J Food Prof 28(6): 111-114.

43. Hasegawa PM (2006). Stress physiology. In: Taiz L, Zeiger E, editors. Plant physiology. 4th ed. Sunderland, Mass. Sinauer Associates 671-705.

44. Brant LA (2002). Calcium the essential mineral. Formulation and Ingredient Challenges, Issue November.

45. Luna-Guzman I \& Barrett DM (2000). Comparison of calcium chloride and calcium lactate effectiveness in maintaining shelf stability and quality of fresh-cut cantaloupe. Postharvest Bio Tech 19: 61-72.

46. Wang, Y, Putnam CD, Kane MF, Zhang Edelmann WL, Carrion RR, Chin DVL, Kucherlapati R, Kolodner RD \& Edelmann W (2005). Mutation in Rpal results in defective DNA double-strand break repair, chromosomal instability and cancer in mice. Nat Genet 37(7): 750-755.

47. Romerao MDN, Alburquerque JM, Valverde F, Guillen S, Castillo D \& Valer M (2013). Postharvest sweet cherry quality and safty maintenance by aloe vera treatments a new edible coating. Postharvest Biol and Tech 39: 93-100.

48. Marpudi SK, Ramchandaran $\mathrm{P} \&$ Srividya N (2007). Alovera gel coating for past harvest quality maintenance of fresh fig fruit. Res. $J$ Pharma Biol Chem Sci 4(1): 43-41.

49. Petersen KPV, Nielsen G \& Bertelsen (1999). Potential of bio based materials for food packaging. Trends in Food Sci and Tech 10: 52-68.

50. AOAC (2012). Official Methods of Analysis. The association of official analytical Chemist, $17^{\text {th }}$ Edn. Chapter 17.

51. Wills, BH \& Pushpurni W (1981). Dehydroascorbic acid levels in fresh fruit and vegetables in relation to total vitamin $\mathrm{C}$ activity. J Agri Food Chem 32(4): 836-838.

52. Southy M, Reich M, Breuils L, jacquemin Y \& Audergon JM (1995). Effect of postharvest calcium treatments on shelf-life and quality of apricot fruit. J Act Hort 384: 619-623.

53. Manganaris GA, Vasilakakis $M$, Diamantidis G \& Mignani I (2007). The effect of postharvest calcium application on tissue calcium concentration, quality attributes incidence of flesh browning and cell wall physicochemical aspects of peach fruits. J Food Chem 100: 1385-1392.

54. Manganris GA, Vasilakakis M, Diamontidis G \& Mignani I (2005). Effect of calcium additives on physicochemical aspects of cell wall pectin and sensory attribute of canned peach prunuspersica (L) Batschcv Andross. J Food Sci Agric 85: 17731778.

55. Southy M, Reich M, Breuils L, jacquemin Y \& Audergon JM (1995). Effect of postharvest calcium treatments on shelf-life and quality of apricot fruit. J Act Hort 384: 619-623.

56. Bhartiya, SP, Sharma RM, Kapoor AP \& Ahmad M (1998). Effect of postharvest chemical treatment on shelf life of apple (Malusdomistica Bork) fruits. Horts $J$ 11(1): 9-16.

57. Bhartiya SP, Sharma RM, Kapoor AP \& Ahmad M (1998). Effect of postharvest chemical treatments on shelf life of apple (Malus domestica Borkh) fruits. Inter $J$ of Horticul 11(1): 9-16. 